\section{Court loss may hurt activists}

\section{Washington}

IN a legal decision that could restrict the tactics of animal-rights investigators, a Las Vegas jury last week found two animal activist groups guilty of defamation and invasion of privacy for distributing a videotape allegedly portraying cruelty to animals.

The jury awarded \$4.1 million to Bobby Berosini, a Las Vegas showman whose act features trained orang utans. Berosini had sued People for the Ethical Treatment of Animais (PETA), America's largest animal rights group, and the Performing Animal Welfare Society (PAWS) for distributing videotapes that show Berosini striking the orang utans backstage with an instrument described as a metal rod.

The verdict could force PETA and other animal rights groups to restrict their distribution of evidence documenting animal abuse in research laboratories, according to PETA attorney Philip Hirschkop. Speaking last week, before the verdict was announced on 11 August, Hirschkop said: "If Berosini can pull this off, it will set animal rights protection back years. Groups will be terrified to go public with allegations." The jury found damages of $\$ 3.1$ million against PETA and $\$ 1$ million against PAWS for defamation, "intrusion into a seclusion" (the camera surreptitiously used to take the videotape had been placed in a private area backstage), invasion of privacy and misappropriation of name (Berosini's name had been used by PETA in articles about cruelty). During the trial, PETA officials and attorneys were fined a total of $\$ 50,000$ for giving a press conference and for publicly accusing District Court Judge Myron Leavitt of conflict of interest. (Leavitt has been a college roommate and law partner of an owner of the Stardust Hotel, where Berosini performs, and has received campaign contributions from the hotel. Leavitt ruled that there was no conflict.) Hirschkop says the groups will appeal against the jury's decision to the state supreme court. If they lose that case as well, they are prepared to appeal to the US Supreme Court, he says.

Dancers in Berosini's show had set up the camera to record what they suspected were regular backstage beatings of the orang utans.

They sent the tapes to PETA and PAWS, both of whom eventually redistributed it. It was shown on the US television programme "Entertainment Tonight". Although the tape is not narrated, PETA has solicited separate opinions from respected primate experts (including Jane Goodall) who found that the tape showed cruelty and gross abuse. Berosini testified that he was simply "correcting" the animals as part of their training.
PETA co-founder Alex Pacheco says that the decision will not stop PETA from distributing evidence of cruelty when it is found. But Hirschkop concedes that the decision is likely to have a "practical devastating effect" on animal-rights investigations.

Because the arguments in the case revolved around whether or not the tape depicted actual cruelty, the Las Vegas case may now impose a burden of legal proof on accusers before they make public allegations of cruelty. "If you're going to allege a fact, you're going to have to make sure that the fact is true", says Steven Wise, president of the Animal Legal ELECTROMAGNETIC RISK

\section{Boston}

JUST a few months after the release of a highly controversial US Environmental Protection Agency (EPA) report* on the health effects of exposure to extremely low-frequency electromagnetic fields (EMF), the federal bandwagon is beginning to roll for more research on the effects of EMF. The EPA report claimed that existing evidence was sufficient to demonstrate a "significant" link between EMF exposure and human cancer (see Nature 345; 463; 7 June 1990).

At congressional hearings late last month, industry and government officials offered virtually unanimous endorsement of a proposed bill that would establish a eral research programme into the effects of electromagnetic fields. Among the bill's provisions are plans for a newly created "Electric and Magnetic Fields Research Advisory Committee" composed of researchers and representatives from government, industry and environpriorities and direction for the new research. The proposed bill is expected to go to the floor of Congress either this autumn or next session.

Support for a greater federal reserch effort marks a surprise change in direction for many participants involved in this issue. Robert San Martin, for example, who testified on behalf of the US Energy Department in favour of a new federal programme, had only several months earlier told Congress that the Energy Department considered its research on electromagnetic fields to be "satisfactory", rejecting suggestions that the agency might increase its effort. And sup-

*Evaluation of Potential Electromagnetic Carcinogenicity, Office of Health and Environmental Assessment, US Office of Health and Environmental Assessment, US
Environmental Protection Agency, 28 June, 1990 (EPA-600/690005 A) coordinated, five-year, \$34-million fedmental organizations to recommend
Defence Fund. "The case may stop people from as quickly characterizing something as cruel." Although the decision is expected to encourage similar lawsuits from researchers who have been targeted by activists, the precedent may be psychological rather than legal. "That door was always open", says Barbara Rich of the National Associations for Biomedical Research. "Just because it wasn't taken, doesn't mean the cases couldn't have been won." And she points out that such lawsuits are still hugely expensive (PETA's legal fees are estimated at $\$ 500,000)$ and tend to involve testimony damaging to both sides. "Most attorneys will tell you it's not worth doing unless you're on some sort of vendetta", she says.

Christopher Anderson

\title{
All aboard the bandwagon
}

port for the federal programme came also from each of the major US electric-utilitybacked groups.

Many questions remain. Observers differ, for example, about which agency should play the lead role in funding and conducting the research. As proposed, the congressional bill would give a primary role to the Energy Department, which currently spends roughly $\$ 3$ million annually on research in this area. But Louis Slesin of the New-York-based trade newsletter Microwave News, who has followed the issue closely for a decade, believes that the lead role should go to an agency "whose main job is public-health related". Slesin says he believes the Environmental is the most likely agency to oversee such a research project, but adds that he is "surprised" by its apparent "nonchalance" about the issue in recent years. In the past, the EPA sponsored research into the health effects of electromagnetic fields, but this was halted in 1986 during the Reagan Administration.

Questions also remain over whether a new federal effort should immediately include research into ways of reducing human exposure to electromagnetic fields and thereby mitigating their potential effects. While there is no decisive verdict on the biological effects of electromagnetic fields, Representative James Scheuer (Democrat, New York) who chaired the recent congressional hearings, stated that we "will have lost little" by initiating such efforts now even if no increased risk is found to be associated with exposure to EMF. Industry representatives, such as James Cunningham, vice-president of the New York Power Authority, however, foresees increased regulation which they believe has yet to be justified by the scientific evidence. As Cunningham put it: "What is needed now is not regulation, but research".

Seth Shulman 